Maurice A. Deane School of Law at Hofstra University Scholarly Commons at Hofstra Law

Hofstra Law Faculty Scholarship

2001

\title{
Wealth Transfer Tax Repeal: Some Thoughts on Policy and Planning
}

Jonathan G. Blattmachr

Mitchell M. Gans

Maurice A. Deane School of Law at Hofstra University

Follow this and additional works at: https://scholarlycommons.law.hofstra.edu/faculty_scholarship

\section{Recommended Citation}

Jonathan G. Blattmachr and Mitchell M. Gans, Wealth Transfer Tax Repeal: Some Thoughts on Policy and Planning, 115243 (2001)

Available at: https://scholarlycommons.law.hofstra.edu/faculty_scholarship/777

This Article is brought to you for free and open access by Scholarly Commons at Hofstra Law. It has been accepted for inclusion in Hofstra Law Faculty Scholarship by an authorized administrator of Scholarly Commons at Hofstra Law. For more information, please contact lawcls@hofstra.edu. 
gression argue, in response, that there is no clear empirical evidence to suggest that the current rate structure significantly undermines the incentive to save and work. But even conceding, as many proponents of progression do, that a progressive rate structure produces some disincentives, they argue that fairness requires a progressive approach and that any resulting inefficiency is a cost worth incurring.

Ultimately, given the lack of definitive empirical evidence as well as the progressive argument that fairness trumps efficiency, any judgment as to the balance between efficiency and fairness is a matter of aesthetics, requiring political resolution. Indeed, in the election just held, the question of progression was hotly contested. Vice President Gore strongly argued for the retention of the current income-tax rate structure and the wealth transfer tax system (with modifications), and President-Elect Bush argued just as strongly for a significant reduction in income-tax brackets and a repeal of the transfer-tax system.

Apparently, perceiving the election's outcome as a mandate of sorts, President-Elect Bush anticipates proposing legislation that would reduce the maximum income-tax bracket to 33 percent and that would repeal the transfertax system. That represents a very serious threat to the progressive character of our present structure. While the reduction in the maximum income-tax rate will certainly have a significant impact on the distribution of the tax burden, it may not, by itself, aiter the percentage of tax revenue paid by the wealthy: The Busin tax-cut proposals aimed at the less wealthy may sufficiently compensate for the reduction in the maximum bracket so as to preserve the current distribution of the burden in terms of income tax revenue.

The elimination of the wealth transfer tax system, however, is a different matter. The system is designed to make the distribution of the tax burden effected under the income tax more progressive while minimizing the disincentive effects inherent in high marginal rates. This is achieved by imposing, under current law, a maximum bracket of 39.6 percent on income as earned, with a deferred tax (the estate tax) at a maximum rate of 55 percent payable on unconsumed resources at death. The disincentive effect, under this kind of approach, is less acute than it would be uncler an equivalent tax rate imposed on income as earned (i.e., 73 percent). To put it concretely, while a taxpayer who faced a 73 percent marginal income tax rate might decide to work less and therefore save less as well, the same taxpayer might very well reach a different conclusion if the rate immediately payable were only 39.6 percent and the balance of the tax (i.e., 55 percent of unconsumed resources) were payable at death. The difference in the taxpayer's reaction is easily understood in that people typically find it difficult to incorporate into their decision-making events that will necessarily occur after their death. In short, by deferring a portion of the tax until death, the estate tax permits a higher rate of tax to be imposed on the wealthy without creating the same disincentive effects that are inherent in an immediate, equivalent income tax. So viewed, the estate tax is not, contrary to the characterization of its opponents, a form of double taxation.

Repeal would unquestionably work a radical transformation in the taxation of wealth transfers. Under repeal, once a taxpayer earned income and paid income tax, no further tax would be imposed on the taxpayer in connection with any transfer of that income by gift or bequest. Nor would the recipient be required to pay income tax on the receipt of the gift or bequest inasmuch as the proposal does not alter the exclusion from gross income under Sec. 102 of gifts, bequests and inheritances - even though miny have thought that Sec. 102's protection for taxpayers wals driven by the fact that transfers were separately taxed under the estate and 
gift tax system. Repeal, therefore, would significantly reduce the level of taxation imposed on wealth transfers and, concomitantly, the share of the tax burden the wealthy are required to bear.

Thus, for those who believe that, as a matter of fairness, the distribution of our tax burden should not be made less progressive, the proposal to repeal the estate and gift tax and simultaneously reduce the maximum income tax rates is an unwelcome development. That is not to say, however, that the estate tax must retain its present form. Those who argue against it often cite the loopholes that exist under current law. It would be difficuit to quarrel with the validity of these criticisms. But accepting them as true does not lead to the conclusion of repeal. The criticisms simply suggest the need for reform. The concern that the burden of the estate tax may fall too harshly on farmers or on taxpayers who cannot, under contemporary standards, be considered wealthy must

\section{$A$ compelling case can \\ Abe mádefor a \\ substantial upward \\ revision in the amount \\ of the exemption (or \\ exemption equivalent) \\ available to farmers, owners of closely held. \\ business interests and \\ other taxpayers as well.}

also be addressed. But, again, the solution-is reform, not repeal. During the campaign, Vice-President-Elect Cheney argued against the estate tax by suggesting that it is wrong to view it as a burden imposed on the wealthy and, by implication, it is consequently wrong to view it as an instrument that helps achieve a more progressive distribution of the tax burden.

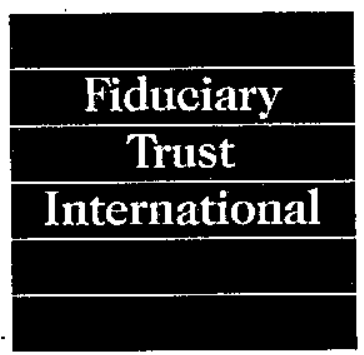

\section{The more volatile the markets, the more clients come to Fiduciary.}

For 69 years, our clients have trusted us to protect and enhance their wealth, from generation to generation. Integrating investment management, tax, trust and estate and custody services. Over $\$ 45$ billion under management. Separately managed portfolios.

NEW YORK • LOS ANGELES • MIAMI • WASHINGTON, D.C. • WILMINGTON LONDON • GENEVA • HONG KONG • MELBOURNE • TOKYO GRAND CAYMAN - GUERNSEY

Inquiries: for accounts of $\$ 2$ million or more, please call Ellen Kratzer or Thomas K. Loizeaux at 877-384-1111
He maintained that the $\operatorname{tax}$ not borne by the transferor but rather by the transferee, who, he claimed, might not be wealthy at all. Since, as suggested, however, the present system imposes the tax on the unconsumed earnings of the transferor on a deferred basis in order to create more progression while minimizing disincentive effects, it seems inappropriate to abandon the tax on the ground that it is paid at death and may therefore fall on less wealthy transferees. But even assuming with the vice-president-elect that it is correct to view the transferee as bearing the burden of the tax, it is unlikely that a transferor who dies with an estate of, say, $\$ 1$ billion will bequeath it to people of such limited economic means so as to call into question the progressive character of the tax.

Moreover, the argument runs contrary to the double-taxation argument repeatedly invoked during the campaign. If, as the vicepresident-elect suggests, the burden of the tax really does fall on the transferee, then no taxpayer is subject to two levels of tax. Rather, the transferor pays tax on income as earned, and the transferee pays tax on the gift or bequest as received.

But, in any event, the answer to the vice-president-elect's argument is once again reform, not repeal: If we seriously believe that wealthy transferors die bequeathing their estates to poor transferees, we can remedy any perceived inequity by creating rules that ameliorate the tax liability, or perhaps even eliminate it, where such inequity occurs (by, for example, repealing the estate tax and subjecting the transferee to income tax on the bequest instead, with an income-averaging device and a special exclusion for transferees having insubstantial resources of their own and receiving small inheritances).

It is worth noting that, while President-Elect Busin has in the aftermath of the election sought to justify the income-tax cut on the ground that a fiscal stimulus is necessary to avert a slowing economy, no such justification has been 
suggested with respect to the repeal of the estate tax. That is not surprising inasmuch as any tax cut designed as such a stimulus would necessarily have to be aimed at taxpayers having a propensity to consume most, if not all, of their tax savings. Clearly, a repeal of the estate tax would not produce a tax savings for taxpayers with such a propensity. Indeed, for the same reason, the proposal to reduce the maximum income tax brackets cannot be justified on the basis of a slowing economy. Even more important, perhaps, many economists believe that, as a general rule, fiscal stimulus is not an appropriate corrective for a faltering economy. They suggest that an expansionary monetary policy provides a more effective remedy. In any event, whatever the merits of fiscal stimulus as a justification for the proposed income-tax cut, it certainly cannot be invoked as an argument in support of repealing the estate tax. Moreover, the cost of estate-tax fepeal may prove to be prohibitive, given the loss in revenue the government will sustain (compounded by the loss of revenue attributable to any income-tax cut) should the economy actually slow down.

The impact of estate and gift tax repeal on philanthropy must also be considered. As presently structured, our tax system offers a subsidy to charity of approximately 73 cents on every dollar contributed during life by high-earning, wealthy taxpayers (the subsidy is 55 cents on the dollar if made at death, though it approaches 80 cents on the dollar if the generation-skipping-tax is taken into account). If the estate tax is repealed and the president-elect's incometax proposal is also adopted, the subsidy for such contributions will fall to no greater than 33 cents on the dollar. It cannot be denied that such a substantial reduction in the subsidy will have a very significant effect on the propensity to make charitable contributions. If we are not to suffer the consequences that flow from diminished philanthropy, Congress will have
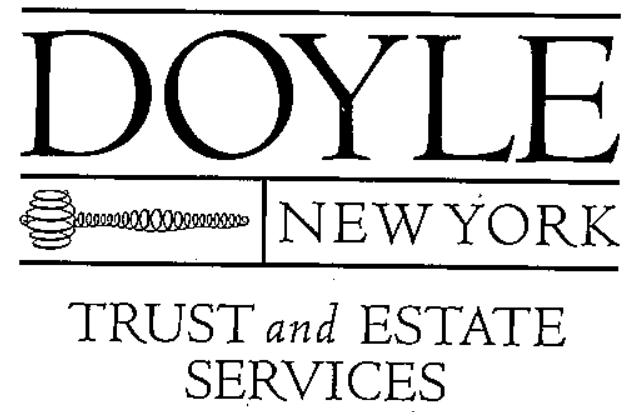

DOYLE NEW YORK is one of the world's foremost estace appraisers and auctioneers of fine art, furniture, decorations, jewelry and a variety of other collecting categories.

At DOYLE NEW YORK, we believe that every estate and client is uniquc. Our goal is to provide exccutors and heirs with a reliable appraisal, followed by the timely liquidation of the property for the highest prices possible. We handle everything. Our commissions and full range of services have always been, and remain, fexible to the necds of our clients.

To receive a copy of our Appraisal and Consignment Services brochure or to schedule an appraisal appointment. plense contact our Trust and Estate Services Department at 212-427-2730 or email info@doylenewyork.corn.
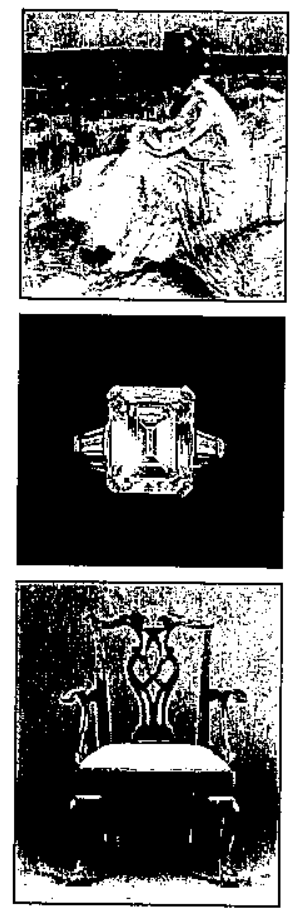

Browse our free, fully illustrated Internet catalogues and leave bids online at www. DoyleNewYork.com

WILLIAM DOYLE GALLERIES I NEW YORK I AUCTIONEERS \& APPRAISERS 175 EAST 87TH ST I NEW YORK I NY 10128 | TEL 212.427.2730 | FAX 212.369-0SO? to replace the tax subsidy with appropriated direct expenditures.

While this is certainly feasible, two points about this approach should be made. First, the cost of direct expenditures should not be ignored in the forthcoming debate about repeal. In other words, it must be viewed as part of the cost of repeal. Second, a direct-expenditure approach flies in the teeth of the notion (often cited by the president-elect) that government intervention should, as a general matter, be limited and that therefore government's role in "picking winners" should not be extended in the absence of an important justification. It would be unfortunate if philanthropy were to become so extensively controlled by government and therefore so rampantly politicized. Indeed, in the case of religious charities, such direct expenditures could even raise constitutional questions (potentially violating the separation between church and state). In short, if the subsidy is to be reduced without precipitating a deleterious reduction in charitable activity, it must be replaced by direct expenditures, entailing its own cost and substantially expanding (to the extent constitutionally permissible) the scope of the government's decision-making authority in the context of philanthropy.

Finally, quite aside from the repeal of the estate tax, the repeal of the gift tax will have its own pernicious effects. The gift tax is ordinarily justified as an adjunct to the estate tax: In the absence of the gift tax, the integrity of the estate tax could not be maintained in that taxpayers would simply make lifetime gifts and thereby defeat the estate tax. The gift tax, however, does have an additional justification. As the Supreme Court has suggested, the gift tax is necessary in order to secure not solely the integrity of the estate tax, but also the integrity of the progressive character of the income tax. (See Dickman v. United States, 465 U.S. 330 (1984).) While those who seek repeal have focused their rhetoric on existing loopholes, farmers and other taxpayers who probably should not subject 
to the tax, they have not considered the ways in which taxpayers will be able to "game" the income tax system, and thereby under. mine its progressive character, if repeal of the gift tax is achieved.

After briefly outlining the repeal proposals, we will then turn our attention to the planning opportunities that we anticipate would become available under repeal and the revenue loss that the states

\section{Republican Estate Tax Repeal Proposals}

Under prior Republican proposals, the estate tax would be phased out over ten years. See, e.g., HR 8. A proposal has now been dirafted, however, under which the estate, gift and generation skipping transfer taxes would be phased out over five years: a reduction of the top rate from 55 percent to 44 percent in the first year, dropping to 33 percent a year later, 22 percent the year after that, then 11 percent one year latter, and then in one more year the tax rate drops will suffer as a result. to zero. A further proposal would also result in a wealth transfer tax elimination: a reduction rate in 2002 to 50 percent; to 45 percent in 2004; to 40 percent in 2005; to 35 percent in 2006; to 25 percent in 2007; to 15 percent in 2008 ; and no tax thereafter. Other proposals under consideration would reduce all brackets, including the entrylevel brackets as well (presumably, the functional equivalent of increasing the unified credit).

Whether it is more accurate to posed on the decedents or the inheritors, if assets are not sold during lifetime; there is no double tax. Most assets transferred by a decedent are entitled to a new income tax basis under Sec. 1014(a) of the Internal Revenue Code ("Code") in the hands of the inheritor equal to their estate tax values. The inherent profit is never subjected to income tax. They are subject to only one level of taxation: the estate tax. In an apparent acknowledgement of that, the view the estate tax as being imprior Republican proposals pro-

vided for income tax basis to ca ryover from the decedent to th inheritors.

However, a proposal being cil culated now would, in many cas es, change the situation from a: alleged double tax to a zero ta: at least for descendants of a mat ried couple. Widows and widow ers would not only continue $t_{1}$ receive property free of estat tax (as everyone would) but re ceive the automatic income ta: free change in basis to the prop erty's value when the first spous: dies. Because most spouses in : first marriage die at about thi same time, the inheritors of a mar ried couple's property will achievt the best of both possible worlds no estate tax and a basis recently refreshed as of the time the firs spouse dies. Indeed, the descen dants need not even wait unti the second parent dies. After the death of the first spouse, the sur. viving spouse can give the de. scendants the assets free of gift tax along with the surviving spouse's new income tax basis.

Estimates have ranged to ove $\$ 1$ trillion of revenue loss to the Federal government over a 20 -year period on account of the repeal of the estate tax system with the actual amount of the loss dependent upon the speed of the pliaseout. Carryover of income tax basis would have made up some portion of that loss but, as explained above, under at least one proposal, the step up in basis would continue to be the rule because so many of the wealthy are married. (And don't worry too much about second or third spouses: the proposal allows the use of a qualified terminable interest property or QTIP-type trust - not to secure the estate tax marital deduction, as that will not be necessary as there will be no estate tax, but to secure the step-up in basis.)

\section{It's your call.}

\section{$1 \cdot 800 \cdot \mathrm{ONE}^{\circ} \mathrm{CALL}^{\left.{ }^{(663} \cdot 2255\right)}$}

Fax $1 \cdot 800 \cdot 663 \cdot 3299$

Internet www.heirsearch.con

Enuil igs@heirsearch.com

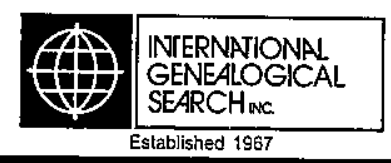

New Planing Opportunities on Unexpected Federal Revenue Loss on Account of Elimination of Gift Tax

Although the public perception is that only the estate tax would be eliminated, the two other wealth transfer taxes, the generation-skip: 
ping transfer tax and the gift tax, also would disappear. The estimated tax loss attributed to repeal includes the loss of revenue from in the generation-skipping transfer tax and the gift tax. But the repeal of the gift tax will create planning opportunities in terms of state and federal income tax, resulting in a revenue loss that must also be included in the "price tag" of repeal.

Without gift tax, high-bracket taxpayers would be well advised to transfer their investments to relatives and trusted friends who are in a lower income-tax bracket. For example, a parent wishes to sell appreciated stock. Rather than selling it herself, she could transfer it to a child who is in a lower tax bracket or has otherwise unused capital losses. The child could sell the stock, paying a lower tax than the parent would have paid. After an appropriate interval, the child could retransfer the sale proceeds to the parent. And, obviously, with repeal in place, neither the transfer nor the retransfer would generate a gift tax. Although the gov- ernment might try to attack such an arrangement as ineffectual in shifting the tax burden from the parent to the child, the government would certainly not be successful under current law - assuming that the sale does not occur immediately after the transfer, the interval between transfer and retransfer is sufficiently long and there is no understanding or agreement calling for retransfer. Nor, in all likelihood, would the government be able to close this loophole effectively through legislation. Any statutory mechanism requiring that the gain be reattributed to the parent where the sale or retransfer occurs within some designated period of time after the transfer would create its own practical difficulties: If the period were not excessive, it would be easy to satisfy, and if it were made too long, it would be unfair to impose an increased tax on the parent merely because the child made an unrelated retransfer to the parent many years after the transfer.

Other strategies will be devel-
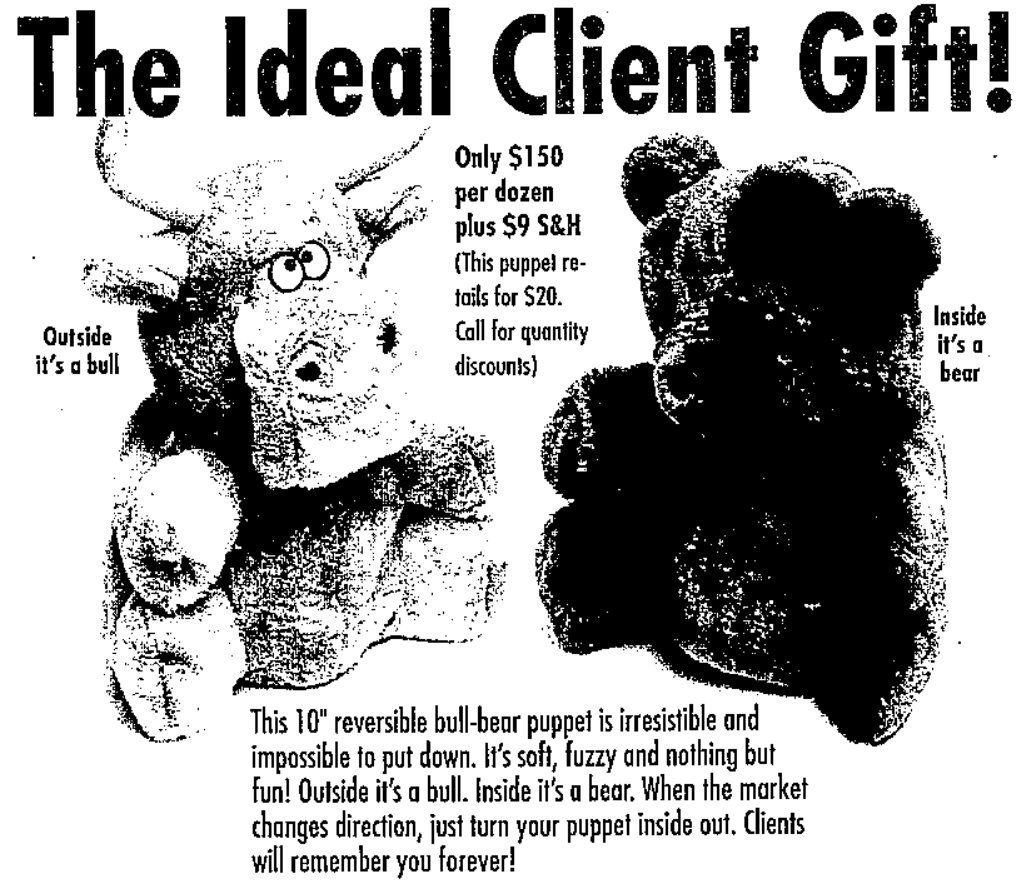

Call 800-621-0720

Or moil your order io: Intertec Publishing Corporation, 18818 Teller Ave., Suite 280, Irvine, CA 92612, Attn: Puppet Dept.
Phone orders call between B:30 a.m. and 4 p.m. Pocilis lime. Visa, Mastercard, Amex, thecks occepted. Make checks payoble to INTERTEC PUBLISHILng CORPORATION. Appropriate soles laxes will apply. Please ollow two weeks for delivery.
SHIPPING \& HANOLING CHQBGES Order subtotal SW arles Stlingkng cluogys an for willies

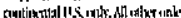
cell tirsthipping dirings. oped. For example, a taxpayer with trusted relatives or friends overseas may well give them almost all of his or her assets that produce portfolio income. The federal withholding rate on U.S. source income paid to foreigners is only 30 percent which is lower than the top fecleral income tax rate on U.S. taxpayers. In fact, if the income is not U.S. but foreign source, the federal government will collect no tax at all. The foreign recipients of gifts from Americans will not have to forego all U.S. investments to avoid U.S. tax. Currently, the United States does not impose tax on calpital gains experienced by foreigners on U.S. investments (such as stocks in U.S. companies) other than American real estate. Interest on most American bonds also is exempt from U.S. tax if paid to a non-U.S. person. Hence, a wealthy Anserican who invests in municipal bonds and has trusted foreign relatives may be able to convert to higher yielding taxable bonds but pay no tax. That concept will be so inviting to some that the least wealthy member of a family may be urged to expatriate. If that family member, at that time, has little income, he or she probably can establish cuite easily that the expatriation was not tax-motivated. See Sec. 877

Taxpayers will also use trusts to reduce or eliminate income tax. Indeed, by eliminating the friction created by the gift tax, repeal will allow taxpayers more easily to create trusts that are not grantor trusts for income tax purposes but nonetheless are for their benefit. A grantor trust is one the income of which is attributed directly back to the grantor as though the trust did not exist. Sec. 671; Rev. Rul. 85-13, 1985-1 CB 184. A trust from which income or principal may be paid to the grantor is a grantor trust unless the payment requires the consent of an aclverse party. See, e.g., Sec. 677(a). An adverse party is one having a substantial beneficial interest in the trust that would be adversely affected by making the payment to the grintor. Under current law, any person who holds such an interest ahnost certainly would be making a taxable gift if he or she consented 
to the payment from the trust to the grantor. Once the gift tax is repealed, adverse parties will be ised to avoid grantor trust status. the income can then be taxed to he trust as a separate and independent taxpayer or can be shifted to any of its beneficiaries. Indeed, the law permits the trustee to wait until after the close of the tax year to determine to which beneficiary or beneficiaries the trustee wishes to tax the income. Sec. 663(b). The trustee may make the income available to a beneficiary who is in a low (or no) income tax bracket, by "crediting" it to the beneficiary who then must report the income as his or her own. Sec. 662(a). If the income, in fact, is distributed to the benEficiary, he or she can return it to the original property owner. Or if it is only credited, the beneficiary may leave it in the trust and, after a time, the trustee may return it to the original property owner with the consent of that beneficiary (an adverse party). Neither the transIfer trust nor the retransfer will be subject to gift tax.

Perhaps, an even better result can be effected by transferring assets to a foreign trust which, like atforeign person, is generally not subject to U.S. income tax. No Ámerican could be a beneficiary; otherwise, the income of the foreign trust will be taxed to the grantor under Sec. 679 of the Code. The income may be accumulated in the trust tax free. The trustee may, from time to time, ask a beneficiary if he or she wishes income or property hiat otherwise would be distribted to the beneficiary to be paid another. It would not be surprising if the beneficiary requested the tristee to give back to the grantor whatever trust assets the trustee Would otherwise distribute to the beneficiary. (Sec. 684 imposes a gains tax if appreciated assets are transferred to a foreign trust if the trust is not a grantor trust. Hence, taxpayer will transfer only unappreciated assets, such as cash, to a foreign trust which is designed not to be a grantor trust.)

Another option will be to create trust described in Sec. 678 of the Internal Revenue Code for another taxpayer who is in a relatively low tax bracket. Under that section, if a beneficiary has the right to withdraw the property from a trust but does not, all income may be taxed to the beneficiary even if, depending on the terms of the trust, the beneficiary loses the right to demand trust property or to receive any distributions in the future. Indeed, after the power to withdraw the property from the trust has disappeared, someone (even the trustee) could add the original property owner as a beneficiary. The income will continue to be taxed to the original beneficiary, even though the trust assets may ultimately be diverted to the original property owner.

To believe that taxpayers will not take such tax avoidance action is naïve. The so-called "spousal remainder trust" became a very popular tool among high income earners until legislation closed it down by the enactment of Sec. 672(e). That Sec. essentially treats a husband and wife as one person for purposes of the grantor trust rules.
Prior to the amendment, the Code permitted a married taxpayer to create a short-term trust, have the income earned during that period taxed to the property owner's child (or someone else in a bracket lower than that of the grantor) and then have the property returned to the grantor's spouse (effectively returning it to the grantor). What made this strategy feasible as a practical matter was the elimination of the gift tax on transfers between spouses beginning in 1982 . It was very popular and extensively used even though (because of gift-tax exposure with respect to the income interest given to the nonspouse) it could produce limited income tax savings. There is little question but that the potential to game the system through bracket-shifting made available by an across-the-board repeal of the gift tax will dwarf in scope the comparatively insignificant abuse unleashed by the introduction of the unlimited marital deduction. The federal government no doubt will create new barriers to some of

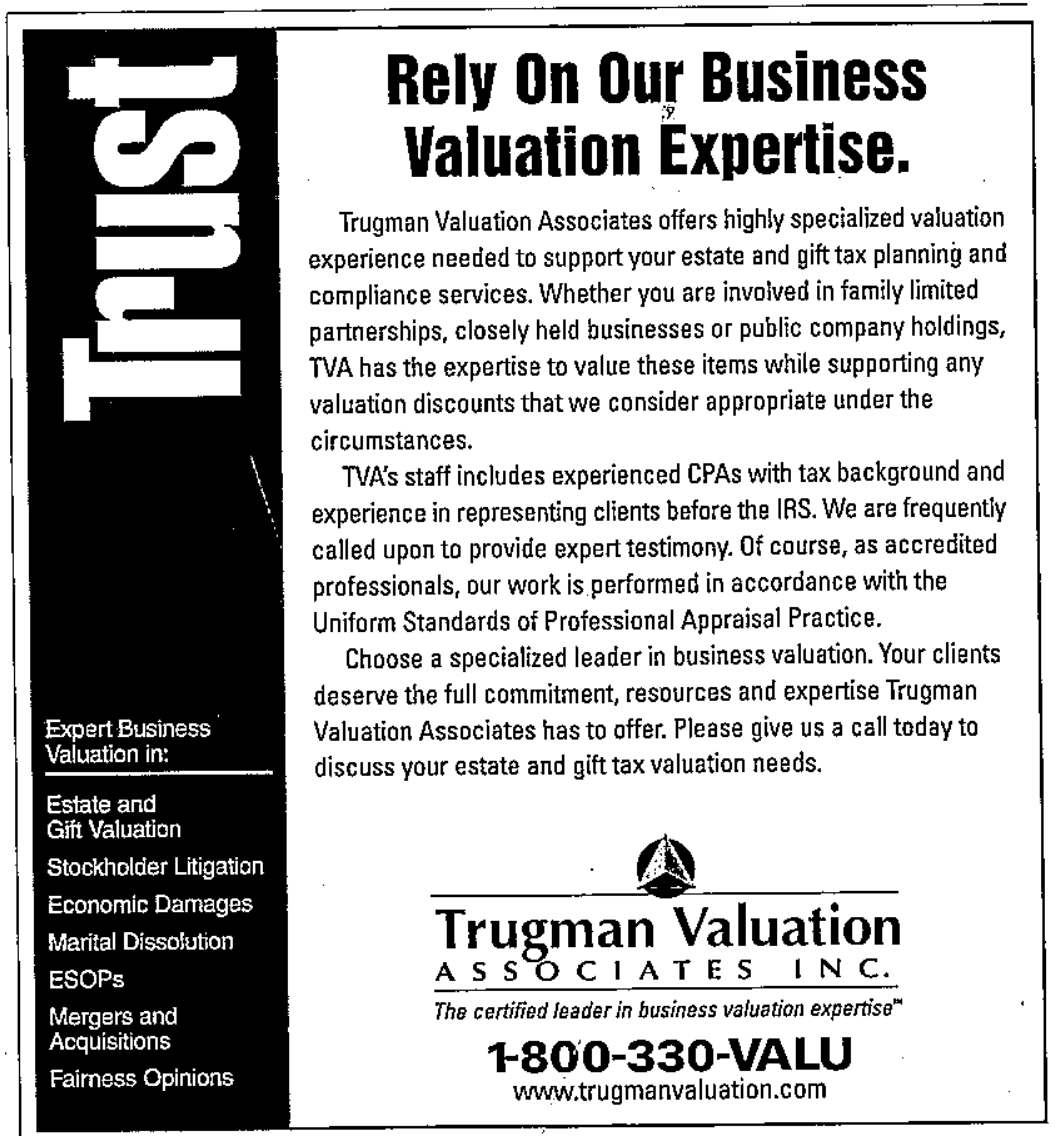


the income tax avoidance arrangements discussed after it has dismantled the gift tax hurdle that has served it so well to prevent such results for nearly 70 years.

\section{The Biggest Losers of All: The States}

There will be many losers as a resuit of the elimination of the wealth transfer tax system. As suggested, charity will be a principal loser. Common estate planning arrangements, such a charitable lead trusts, that benefit both individuals and charity and may substantially reduce gift and estate tax, will disappear, as will most direct bequests to charity at death - not to mention the decline in lifetime giving that, as suggested, will occur as well. Second, some married women (and men) will lose. A majority of states provide for a surviving spouse to receive a minimum share (typically, one-third) of the deceased spouse's estate. However, the share only applies to assets owned at death (and, in some jurisdictions, those given away within one or two years of death.) Without gift tax, individuals who do not wish their spouses to share in as much property as they otherwise would will make gifts to trusts for themselves or to others prior to death. With repeal, the gift tax will no longer impede such planning (although the states could address this issue). It may well be that women will suffer the consequences of such a shift in planning more than men. However, the biggest losers of all of the elimination of the federal wealth transfer tax system will be the several states.

First, every state, without exception, imposes a death tax equal to the state death tax credit. That credit, which reduces the gross federal estate tax, dollar-for-clollar, up to the limit set forth in Sec. 2011, represents revenue sharing from the federal government to the states and comprises about 20 percent of the total estate tax bills paid. It probably represents a loss in excess of $\$ 100$ billion to the states in the next ten years. In some states, the state death tax credit is a significant

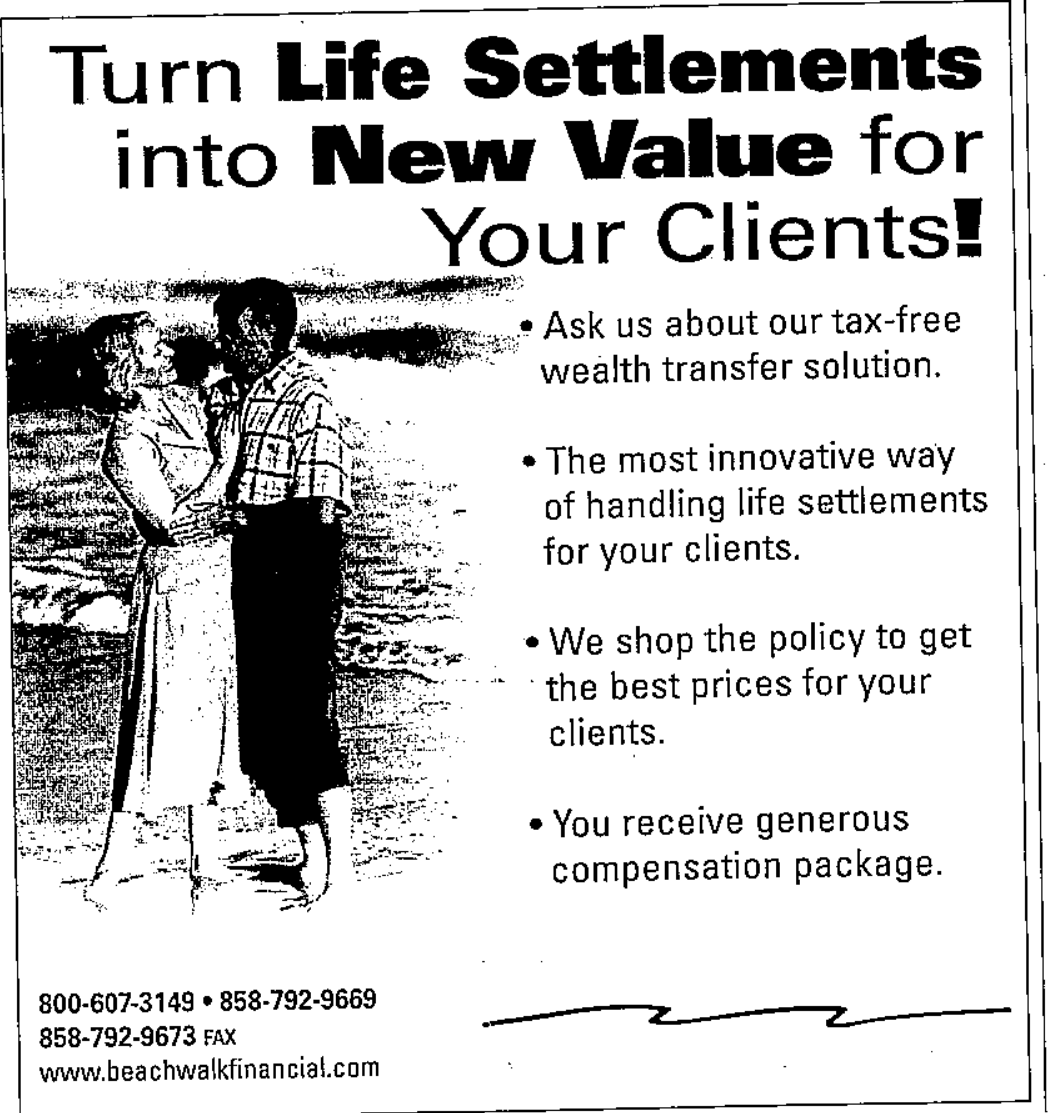

part of the arinual state budget. In New Hampshire, for example, it is 4.5 percent. In New York, Florida and Connecticut, it is over 2.5 percent. Some states might adopt in: dependent estate tax systens, although that may be politically impossible. For some states, such as Florida, it cannot be done: That state's constitution prohibits the imposition of an independent estate tax. Such states have no easy mechanism to replace the lost revenue.

However, 43 of the 50 states (along with the District of Columbia) will face an even more serious, additional revenue loss. Those 43 states (and the District) impose state income taxes. (Some state political subdivisions, such as New York City and Philadelphia, also impose an income tax and they also will be affected.) They will lose tremendous income tax revenue if the wealth transfer tax system is repealed. The reason is the simplicity with which individual taxpayers in one state may shift their income, under repeal, to others in states with lower or no state income taxes. The taxpayer does not even have to search for a trusted person in a lower federal bracket, just one (or more) who resides in a jurisdiction without state (or local) income tax.

Indeed, it seems likely that individuals will create trusts that are not grantor trusts (relying on the adverse party technique discussion above) for income tax purposes with their portfolio assets and of which they are beneficiaries. The trusts will be created in jurisdictions that will not impose income tax on the trust's income. Alaska, Delaware, Florida, Nevada, South Dakota, Texas, Wyoming and Washington (State) appear to be excellent choices at this time. The trustee may accumulate current income in the trust, pay the current fecieral income tax, and then distribute that income to the trust's grantor in a later year. Little tricks will be developed to minimize income tax on the return of property to the grantor. For eximple, after four years of accumulating income, the trustee distributes all assets to the grantor on the first day of the fifth year. There will be no or minimal in- 
come for that one day so the grantor will include nothing, or almost nothing, in income. (Under current law, a beneficiary must include as income the trust's income for the year in which the beneficiary receives trust assets, as a general rule. See Sec. 662. However, for U.S. trusts, no income of a prior year of the trust is included in the beneficiary's income.)

To think individuals will not try to avoid state income tax once the barrier of gift tax is brought down is even more naïve than to think they will not try to reduce their federal income tax by income shifting. Indeed, individuals will attempt to techaracterize what would have been earned income (e.g., salary) into passive income to try to effect a shift to others outside of the home" state. Cf. Van Zandt v. Commissioner, 341 F. 2d 440 (5th (ir.), cert. denied, 382 U.S. 814 (1965). The IRS will have no incentive to try to attack such income-shifting arrangements where the federal revenue is not affected. Smart taxpayers will arrange their affairs so the IRS receives no less (and possibly arrange it so the federal government gets a little more) but the states receives nothing.

\section{What Can Be Done to Avoid the Loss of State Death and Income Tax Revenue}

As indicated earlier, the states, perhaps, can be convinced that the loss of state death tax will not be significant or they (other than Florida and perhaps a few others) can pass new death tax systems so their revenue will not be eroded.

The loss of state income tax on passive income is more serious for itwo reasons. First, it represents a 1 much larger portion of the revenue to most states. Second, the states probably cannot pass and enforce laws that would cause residents of their states to report income on assets given to others. Special throwback rules (cf. Secs. 665-668 prior to 1997), special attribution of income rules, special state grantor trust rules, state anticipatory assignment of income rules and other special provisions designed to prevent erosion of state income tax on passive income will be very dif- ficult for a single state to enforce. (It should be noted that the reduction in state income tax will reduce the federal income tax deduction under Sec. 164 and thereby increase Federal income taxes.)

An alternative would be for the Federal government to adopt a surcharge on passive income, such as gains, dividends and interest and allow a dollar-for-dollar state income tax credit, functioning as the state death tax credit under Code Sec. 2011 has operated. Individuals would have less or no incentive to try to avoid the state income tax on such income. It would seem fair that if the Federal government believes it is beneficial to eliminate the wealth transfer tax system that it alone should bear the revenue loss burden and not shift a significant portion of the cost to the states.

In turn, a state income tax crediting system has other ramifications. One is the inability of a state to determine how much income tax to impose. Jurisdictions such a California and Oregon probably cannot be assured of the same high level of state income tax they have imposed in the past. Also, depending upon the exact structure of the crediting system, it may cause different kinds of income to be subjected to different rates of tax. In addition, it is unlikely the federal government will provide any level of subsidy to localities (such as New York City) with a crediting system. Those political subdivisions are even less prepared to fight the shifting of passive taxable income. They will have to turn to other forms of taxation, such as sales taxes, effecting a regressive shift in the tax burden. Perhaps, most important, any surcharge on passive income could prove to be problematic in terms of efficiency. To the extent that such a surcharge results in the imposition of an aggregate tax on income from savings that is higher than that currently imposed by the states, taxpayers could respond by saving less.

\section{Saving the Family Farm and Retaining the Tax}

Under current law, an individual can own a farm or other closely-held company worth more than
\$2 million and pay no death tax at all on account of the estate tax exemption equivalent under Sec. 2010 and qualified family owned business interest exclusion under Sec. 2057(combined reaching $\$ 1.3$ million) and special use valuation of farm and certain other business use real estate under Sec. 2032A (that can exclude another $\$ 800,000$ in value). For a married couple, the value can exceed $\$ 4$ million and, in some cases, be even greater. (See Sec. 2031(c) relating to certain conservation easement real estate.)

Given that the objective of the estate tax is to make the distribution of the tax burden more progressive and that it is important therefore for the tax to fall on the wealthy, a compelling case can be made for a substantial upward revision in the amount of the exemption (or exemption equivalent) available to farmers, owners of closely held business interests and other taxpayers as well. And, certainly, the generation-skipping tax exemption should be concomitantly increased.

In sum, in our view, the loopholes and deficiencies inherent in current law can be fixed. Indeed, we believe strongly that reform must ibe undertaken. But we believe just as strongly that repeal would be the wrong remedy.

\section{Jonathan G. Blattmacbr is a} member of the firm of Milbank, Tweed, Hadley \& McCloy, LLP, an author of four books and several articles on estate planning topics. He also is the author and co-developer of Wealth Transfer Planning, a computerized estate planning system published by the Tecbnology Group, Inc. of Baltimore Maryland and that can be vieued at www.lawontheweb.com.

Mitchell Gans was formerly an Associate in the Tax and Tirust Estates Departments at Simpson, Thacber $\hat{\sigma}$ Bartlett and law clerk to Hon. Jacob D. Fuchsberg; Associate Judge, New York State Court of Appeals. He bas lectured extensively to various bar. associations concerning taxation and trusts and estates issues. 